\title{
Patients' and General Practitioners'Views About Preventive Care in Family Medicine in Switzerland: A Cross-sectional Study
}

\author{
Christine Cohidon ${ }^{1,2}$, Fabienne Imhof ${ }^{1,2}$, Laure Bovy ${ }^{1,2}$, Priska Birrer ${ }^{1,2}$, Jacques Cornuz ${ }^{2}$, Nicolas Senn ${ }^{1,2}$ \\ ${ }^{1}$ Department of Family Medicine, University of Lausanne, Lausanne, Switzerland; ${ }^{2}$ Center for Primary care and Public Health (Unisanté), University \\ of Lausanne, Lausanne, Switzerland
}

Objectives: The aim of this study was to describe general practitioners (GPs)' opinions and practices of preventive care and patients' opinions, attitudes, and behaviors towards prevention.

Methods: The data stemmed from a cross-sectional national survey on prevention conducted in Switzerland from 2015 to 2016. In total, 170 randomly drawn GPs and 1154 of their patients participated. The GPs answered an online questionnaire and the patients answered a questionnaire administrated by fieldworkers present at their practices.

Results: Both patients and GPs agreed that delivering preventive care is the dedicated role of a GP. It appeared that beyond classical topics of prevention such as cardiovascular risk factors, other prevention areas (e.g., cannabis consumption, immunization, occupational risks) were scarcely covered by GPs and reported as little-known by patients. In addition, GPs seemed to use a selective approach to prevention, responding to the clinical context, rather than a systematic approach to health promotion. The results also highlight possibilities to improve prevention in family medicine through options such as more supportive tools and public advertising, more time and more delegated tasks and, finally, a more recognized role.

Conclusions: Despite an unfavorable context of prevention within the healthcare system, preventive care in family medicine is reasonably good in Switzerland. However, some limitations appear regarding the topics and the circumstances of preventive care delivery. A global effort is needed to implement necessary changes, and the responsibility should be broadened to other stakeholders.

Key words: General practitioner, Preventive care, Patients, Attitude, Practices, Switzerland

\section{INTRODUCTION}

The global burden of non-communicable diseases is one of the most important concerns of healthcare systems. Further-

Received: July 5, 2019 Accepted: September 4, 2019

Corresponding author: Christine Cohidon, PhD

Department of Family Medicine, University of Lausanne, 44 Rue du

Bugnon, CH-1011 Lausanne, Switzerland

E-mail: christine.cohidon@hospvd.ch

This is an Open Access article distributed under the terms of the Creative Commons Attribution Non-Commercial License (http://creativecommons.org/licenses/bync/4.0/) which permits unrestricted non-commercial use, distribution, and reproduction in any medium, provided the original work is properly cited. more, smoking, excessive drinking, lack of physical activity $(\mathrm{PA})$, and poor dietary habits have been shown to play a major role in the development of these diseases [1]. Several studies have shown that actions aimed at reducing these risky behaviors reduce disease incidence and the resulting costs [2-7]. Likewise, there is general agreement among healthcare professionals (national and international medical academies) and physicians themselves that preventive care should represent a substantial part of activities performed in family medicine [816]. In this way, with their proximity to communities and overall knowledge of their patients' lifestyles, general practitioners (GPs), or primary care providers, should be in the front lines of 
this mission.

Most studies investigating the delivery and effectiveness of preventive care in family medicine have focused on barriers and facilitators, such as the personal attributes of physicians, personal factors related to patients, and the role of public policy. In brief, although GPs generally report that they feel it is their role to offer preventive care, it is often difficult for them to perform adequately, mainly due to a lack of time or feelings of ineffectiveness [8,17-28]. Beyond these studies on whether GPs can or cannot deliver preventive care, descriptions of current practices of preventive care by GPs are scarce. Moreover, it seems that when GPs perform preventive care, it is more likely to occur during the management of acute or chronic clinical conditions than as truly proactive preventive activities. In other words, primary prevention or health promotion seems to have only been implemented to a limited extent $[21,29]$.

In addition, reports of patients' attitudes toward preventive care are limited in the literature. It remains unclear whether patients feel adequately informed about certain prevention topics, whether they expect to get the information from their GPs or others, and whether they usually adopt a healthy way of life. Finally, very few studies have offered a joint perspective of family physicians' and patients' opinions of prevention, providing the opportunity to determine whether they align.

In the Swiss health care system, which is mainly a fee-forservices system, the health insurance domain does not value preventive activities. In general, preventive care can be provided during a consultation, but not as a separate specific service. Therefore, physicians have no major incentive to perform prevention work. Along these lines, the attitudes and practices of health professionals and patients are interesting to explore. In the present study, we aimed to describe the actual state of preventive care provided by GPs in their practices, alongside the opinions, attitudes, and behaviors of their patients.

\section{METHODS}

\section{Study Design and Population}

From 2015 to 2016, a large study about prevention in family medicine was launched in Switzerland. The objective of the study was to obtain information on the opinions, attitudes, and practices regarding prevention among GPs and their patients.

The study was carried out through the Swiss Primary Care Active Monitoring (SPAM) family-physician network, including
277 randomly selected GPs (at the time of the study, in 2015). The SPAM network was created in 2012 from a comprehensive list of GPs formed using lists of members from the Association of Family Doctors and Pediatricians and the Swiss Society of General Internal Medicine. The physicians were asked whether they would be willing to participate in a research network that was subsequently labeled the SPAM network. The representativeness of the network group in terms of sex, age, and rural/ urban location was cross-checked against national statistics and considered satisfactory [30]. We asked the 277 GPs to answer an online questionnaire about their opinions, attitudes, and practices regarding preventive medicine. Fieldworkers collected data from the patients at each practice on a set day. In the waiting room, at different moment of the day, they asked patients to fill in a questionnaire until a response of at least 10 patients had been reached. The data collection took place between August 2015 and May 2016.

\section{Data}

\section{General practitioner questionnaire}

The GP questionnaire comprised 4 sections. The first investigated socio-demographic features of the GPs, including sex, age, years of experience in practice, and practice location (i.e., linguistic area, reflecting the fact that Switzerland has 3 main geographic areas corresponding to 3 linguistic areas [German, French and Italian] and rural/urban area). The second section asked in detail about the practice's organization and function (group/solo practice, other activities beyond standard consultations, consultation length, weekly workload, number of consultations a day, use of shared electronic records, availability of a pharmacy at the practice). The third section assessed primary prevention provided by the GP, mainly in terms of counseling about various prevention topics (smoking and drinking habits, cannabis consumption, dietary habits, PAs, overweight, affective and sexual life, cardiovascular risks and occupational risks, and immunization and screening practices). The fourth section investigated the GP's attitude towards prevention, focusing on the role of the GP, training, and obstacles to delivering preventive care.

\section{Patient questionnaire}

The patient questionnaire included 5 sections. The first explored the patient's socio-demographic features. The second elicited the patient's opinions about prevention and health education. The third section of the questionnaire asked about 
lifestyle habits and risky behavior in terms of smoking, drinking, eating habits, PA, sleeping habits, and screen time (seen as an indirect indicator of PA and as a factor that could generate sleep disorders). The fourth section explored the patient's practices regarding his or her use of care, in particular his or her use of preventive care (mainly cancer screening and vaccinations). The final section investigated diseases, treatment, and adherence.

We initially wrote the questionnaires in the French language. A panel of local GPs and patients tested the questionnaire to ensure comprehension and a non-judgmental tone. We then translated them into the German and Italian languages.

\section{Statistical Analysis}

We described patients' and physicians' opinions, attitudes, and practices pertaining to prevention in family medicine in terms of frequency, percentages for categorical variables, and median and mean for continuous variables. We performed statistical analyses using Stata version 14.2 (StataCorp., College Station, TX, USA).

\section{Ethics Statement}

The Ethical Review Board of the Canton of Vaud approved the survey ( $\left.{ }^{\circ} 74 / 15\right)$. Written informed consent to participate was obtained from all patients.

\section{RESULTS}

\section{Sample Characteristics}

Of the 277 physicians in the SPAM network, 167 completed the online survey (response rate, 60\%). Additionally, 1157 of their patients answered the patient questionnaire at the physicians' practice in the presence of fieldworkers. We present the physicians' and patients' characteristics in Table 1. The physicians were mainly males (69.5\%), with a median age of 56 years and a median of 18 years of experience in practice. Slightly more patients were females (56.6\%), with a median age of 61 years.

\section{Patient Opinions and Attitudes About Preventive Care}

According to the patients, preventive care should be the mission of their GP (84.1\%) and they consider him/her to be the best source of information in this domain (83.4\%). Half of patients believed that the media are also a good source of in-
Table 1. Patients and family physicians' characteristics

\begin{tabular}{lc}
\hline Variables & n (\%) or $\mathbf{n}$ [median] \\
\hline Patients' characteristics (n=1153) & $652(56.6)$ \\
Sex (female) & $1153[61]$ \\
Age & $863(74.8)$ \\
Country of birth (Switzerland) & \\
Marital status & $717(62.2)$ \\
Couple & $322(27.9)$ \\
Alone & $114(9.9)$ \\
Other & \\
Employment status & $439(38.1)$ \\
Employed & $490(42.5)$ \\
Retired & $223(19.4)$ \\
Other & \\
GPs' characteristics ( $n=167)$ & $51(30.5)$ \\
Sex (female) & $167[56]$ \\
Age & $164[18]$ \\
Years of experience in practice & \\
Practice organization and function & $158(12.0)$ \\
Practice in rural area & $157(63.7)$ \\
Use of shared health electronic records & $159(20.0)$ \\
Consultation length & $155(44.0)$ \\
Weekly workload (hr/wk) & 158 of face-to-face consultations/d \\
No. of & \\
\hline
\end{tabular}

GPs, general practitioners.

formation (50.8\%). More than half of the patients (58.4\%) used the Internet to look for health advice, and $12.2 \%$ of them did so at least once a week. The feeling of being well informed was contrasting; patients reported finding good information about smoking and alcohol drinking, but were not as well informed for other topics of prevention, in particular new epidemics (35.5\% poorly informed), cannabis consumption (32.6\%), immunization (25.4\%), sexually transmitted diseases (STD, 23.2\%), depression (23.9\%), and cardiac diseases (22.8\%). Furthermore, patients reported that over the 12-month period, they mainly received preventive care advice from their GP about PA (40.1\%) and dietary habits (37.0\%), but less frequently about sleeping habits (28.7\%) and obesity (22.5\%). Some prevention topics, such as STD and contraception, drug consumption and oral hygiene, were poorly reported $(<5 \%)$. These findings are summarized in Table 2.

\section{Patient Risky Behaviors}

As shown in Table 2, most patients reported regularly engaging in $\mathrm{PA}$, with $52.6 \%$ practicing $\mathrm{PA}$ once a week or more. The vast majority believed that they had good dietary habits 
Table 2. Patients' attitudes and behaviors pertaining to prevention in family medicine ( $\mathrm{n}=1154)$

\begin{tabular}{|c|c|c|c|}
\hline $\begin{array}{l}\text { Patients' global opinion regarding } \\
\text { prevention and GP }\end{array}$ & $\begin{array}{l}\text { Prevention-related } \\
\text { items, } \%\end{array}$ & $\begin{array}{l}\text { Patients' global opinion regarding } \\
\text { prevention and GP }\end{array}$ & $\begin{array}{l}\text { Prevention-related } \\
\text { items, \% }\end{array}$ \\
\hline Prevention is a GP's mission & & Cardiac diseases & \\
\hline Yes & 84.1 & Poorly or very poorly informed & 22.8 \\
\hline No & 11.7 & Very well or well informed & 75.8 \\
\hline I don't know & 4.2 & Don't know & 1.4 \\
\hline A healthy way of life is necessary to provide & & Smoking habits & \\
\hline good preventive care & & Poorly or very poorly informed & 5.7 \\
\hline Yes & 50.2 & Very well or well informed & 93.4 \\
\hline No & 44.6 & Don't know & 0.9 \\
\hline I don't know & 5.1 & Alcohol & \\
\hline Patients' best sources of information ${ }^{1}$ & & Poorly or very poorly informed & 6.7 \\
\hline Family physician & 83.4 & Very well or well informed & 92.3 \\
\hline Other physician & 11.8 & Don't know & 1.0 \\
\hline Other healthcare professional & 10.6 & Cannabis consumption & \\
\hline Pharmacist & 16.1 & Poorly or very poorly informed & 32.6 \\
\hline Relatives & 22.0 & Very well or well informed & 64.6 \\
\hline Media & 50.8 & Don't know & 2.8 \\
\hline Efficacy of advertising slogans & & Contraception & \\
\hline Very effective & 10.3 & Poorly or very poorly informed & 12.9 \\
\hline Somewhat effective & 20.0 & Very well or well informed & 83.2 \\
\hline Slightly effective & 24.9 & Don't know & 3.9 \\
\hline Not effective & 37.7 & STD & \\
\hline I don't know & 7.1 & Poorly or very poorly informed & 23.2 (STD)/17.5 (HIV) \\
\hline Frequency of Internet use for health information & & Very well or well informed & 72.9 (STD)/79.3 (HIV) \\
\hline Never & 41.6 & Don't know & 3.8 (STD)/3.2 (HIV) \\
\hline$<1 /$ mo & 31.1 & Occupational risks & \\
\hline $1-2 / \mathrm{mo}$ & 15.1 & Poorly or very poorly informed & 20.8 \\
\hline $1 /$ wk & 5.9 & Very well or well informed & 75.0 \\
\hline$>1 /$ wk & 6.3 & Don't know & 4.3 \\
\hline Patients' feeling of being informed & & Patients' risky behaviors & \\
\hline Environmental risk & & Smoking habits & \\
\hline Poorly or very poorly informed & 19.5 & Never & 49.9 \\
\hline Very well or well informed & 79.3 & Ex-smoker & 28.6 \\
\hline Don't know & 1.2 & Current smoker & 21.5 \\
\hline Immunization & & Instances of drinking (or no of occasions) & \\
\hline Poorly or very poorly informed & 25.4 & Never & 23.2 \\
\hline Very well or well informed & 71.9 & $\leq 1 / \mathrm{mo}$ & 19.7 \\
\hline Don't know & 2.7 & $2-4 / m o$ & 23.2 \\
\hline New epidemics & & 2-3/wk & 21.8 \\
\hline Poorly or very poorly informed & 35.5 & $\geq 4 /$ wk & 10.4 \\
\hline Very well or well informed & 62.6 & Excessive alcohol consumption ( $\geq 6$ units at a time) & \\
\hline Don't know & 1.8 & Never & 72.2 \\
\hline Cancer & & $<1 / \mathrm{mo}$ & 17.2 \\
\hline Poorly or very poorly informed & 19.2 & $1 / \mathrm{mo}$ & 6.7 \\
\hline Very well or well informed & 79.7 & $1 / w k$ & 1.6 \\
\hline Don't know & 1.1 & $>1 /$ wk & 0.6 \\
\hline Depression & & Cannabis consumption (during last month) & \\
\hline Poorly or very poorly informed & 23.9 & Yes & 4.6 \\
\hline Very well or well informed & 74.2 & No & 95.2 \\
\hline Don't know & 1.9 & Do not want to answer & 0.2 \\
\hline
\end{tabular}


Table 2. Continued from the previous page

\begin{tabular}{lc}
\hline $\begin{array}{l}\text { Patients' global opinion regarding } \\
\text { prevention and GP }\end{array}$ & $\begin{array}{c}\text { Prevention-related } \\
\text { items, \% }\end{array}$ \\
\hline Physical activities & 33.6 \\
Very often (>1/wk) & 19.0 \\
Often (1/wk) & 20.1 \\
Occasionally & 27.2 \\
Never & \\
Sense of healthy dietary habits & 82.4 \\
Yes & 14.1 \\
No & 3.4 \\
I don't know & \\
Overweight perception & 0.9 \\
Too thin & 2.0 \\
Somewhat thin & 48.6 \\
Good weight & 41.6 \\
Somewhat fat & 6.8 \\
Too fat & $<0.1$ \\
I don't know & \\
Total screen time (hr/d) & $3.3[2.5]$ \\
Mean [median] & \\
Screen time per day excluding occupational time (hr) & $2.5[2.0]$ \\
Mean [median] & \\
Sleeping habits: duration (hr) & $7.5[7.0]$ \\
Mean [median] & \\
\hline
\end{tabular}

GP, general practitioner; STD, sexually transmitted disease; HIV, human immunodeficiency virus.

${ }^{1}$ Multiple responses were possible.

(82.4\%). However, $48.4 \%$ thought that they were somewhat fat or too fat. The average sleep duration was 7.5 hours and the mean total screen time per day was 3.3 hours (median, 2.5 hours). Furthermore, $27.8 \%$ of patients reported excessive alcohol consumption ( $\geq 6$ units at 1 time).

\section{General Practitioners' Opinions and Attitudes About Preventive Care}

In general, GPs agreed (or strongly agreed), that preventive care is one of their roles, with a frequency varying from $80 \%$ to $99 \%$ according to the preventive care topic. The topics they felt less concerned about related to occupational risks (83.1\%) and affective and sexual life (80.0\%). Approximately $50 \%$ of the GPs (52.5\%) declared that they were not reimbursed enough for preventive care. They believed that they could do a better job of prevention with more supportive tools (70.4\%), better training (59.6\%), and more delegated tasks (80.3\%). Finally, $35.5 \%$ of them reported their feeling of effectiveness as poor or null. These findings are summarized in Table 3.

\section{Counseling for Primary Prevention}

At the first visit, smoking habits (34.3\%) were the major risk factor explored by GPs, followed by PA (25.9\%). However, PA was the most common topic discussed between physicians and patients in routine visits (43.7\%). During these visits, $21.8 \%$ of the physicians never discussed oral hygiene (Figure 1).

\section{General Practitioners' Preventive Practices}

Screening for colorectal cancer was the major form of cancer screening proposed (most often-performed by other specialists, depending on the cancer) by the GPs (89.3\%) (Table 3). Screening for symptoms such as cognitive or depressive symptoms, or for occupational risk exposure, sleep disorders, or violence was usually performed if the GP thought it to be indicated, or upon a patient's request. Fewer than $25 \%$ of the GPs reported spontaneous regular screening of these types of symptoms. A similar situation was observed for human immunodeficiency virus (HIV) screening. In contrast, the GPs more often looked for risk factors of diabetes or cardiovascular disease in routine visits. Notably, the vast majority of the GPs proposed seasonal flu vaccination to their high-risk patients.

\section{DISCUSSION}

The novel approach of this national project enabled us to report patients' and their GPs' opinions and attitudes towards prevention. Preventive care is currently little valued by the Swiss healthcare system. On the side of GPs, few preventionrelated activities are included among billable activities. However, on the side of patients, a broad range of preventive care, such as screenings and immunization, is covered by compulsory medical assurance. It should be noted, however, that no prevention-related activities are covered in the dental field. The results show that Swiss patients and GPs agree that providing preventive care is a dedicated role of the GP, rather than other health professionals. At the same time, the patients underscored the role of the media as the second-best source of information for prevention even though they were wary of advertising slogans. Surprisingly, roughly 4 out of 10 patients never used the internet to look up health information. In 2009, an American study reported that around $61 \%$ of American people used the internet for health information seeking [31]. However, for Europeans, health professionals are the main source of health information by far $(45.3 \%$ of the EU population), followed by traditional media sources, such as television 
Table 3. General practitioners' opinions, attitudes, and practices pertaining to prevention in family medicine $(n=167)$

\begin{tabular}{|c|c|c|c|c|}
\hline \multirow{2}{*}{$\begin{array}{l}\text { Variables } \\
\text { Is it your role to provide } \\
\text { preventive care } \\
\text { regarding... }\end{array}$} & \multicolumn{3}{|c|}{ Preventive care } & \\
\hline & $\begin{array}{l}\text { Strongly } \\
\text { agree or } \\
\text { agree }\end{array}$ & $\begin{array}{l}\text { Disagree } \\
\text { or strongly } \\
\text { disagree }\end{array}$ & $\begin{array}{l}\text { Don't } \\
\text { know }\end{array}$ & \\
\hline Smoking habits & 98.8 & 1.2 & - & \\
\hline Alcohol consumption & 98.8 & 1.2 & - & \\
\hline Cannabis consumption & 93.8 & 6.2 & - & \\
\hline Dietary habits & 96.9 & 3.1 & - & \\
\hline Physical activities & 97.5 & 2.5 & - & \\
\hline Overweight ${ }^{1}$ & 95.7 & 4.3 & - & \\
\hline Affective and sexual life & 80.0 & 20.0 & - & \\
\hline Cardiovascular risk & 99.4 & 0.6 & - & \\
\hline Occupational risk & 83.1 & 16.9 & - & \\
\hline Cancer screening & - & - & - & \\
\hline $\begin{array}{l}\text { Do you feel comfortable } \\
\text { to provide preventive } \\
\text { care regarding... }\end{array}$ & $\begin{array}{c}\text { Easy or } \\
\text { somewhat } \\
\text { easy }\end{array}$ & $\begin{array}{l}\text { Uneasy or } \\
\text { t somewhat } \\
\text { uneasy }\end{array}$ & $\begin{array}{l}\text { Don't } \\
\text { know }\end{array}$ & \\
\hline Smoking habits & 92.0 & 8.0 & - & \\
\hline Alcohol consumption & 65.4 & 34.6 & - & \\
\hline Cannabis consumption & 64.0 & 36.0 & - & \\
\hline Dietary habits & 88.8 & 11.2 & - & \\
\hline Physical activities & 92.6 & 7.4 & - & \\
\hline Overweight ${ }^{1}$ & 81.8 & 16.9 & 1.3 & \\
\hline Affective and sexual life & 43.5 & 56.9 & 0.6 & \\
\hline Cardiovascular risk & 97.5 & 2.5 & - & \\
\hline Occupational risk & 79.3 & 19.4 & 1.3 & \\
\hline Cancer screening & 98.8 & 1.2 & - & \\
\hline \multirow[t]{2}{*}{$\begin{array}{l}\text { Do you feel effective in } \\
\text { your preventive care? }\end{array}$} & $\begin{array}{c}\text { Very } \\
\text { effective }\end{array}$ & $\begin{array}{l}\text { Rather } \\
\text { effective }\end{array}$ & $\begin{array}{l}\text { Slightly } \\
\text { effective }\end{array}$ & $\begin{array}{c}\text { Not } \\
\text { effective }\end{array}$ \\
\hline & 10.3 & 54.2 & 34.8 & 0.7 \\
\hline $\begin{array}{l}\text { How to be better in } \\
\text { prevention activities? }\end{array}$ & $\begin{array}{l}\text { Strongly } \\
\text { agree or } \\
\text { agree }\end{array}$ & $\begin{array}{l}\text { Disagree } \\
\text { or strongly } \\
\text { disagree }\end{array}$ & $\begin{array}{l}\text { Don't } \\
\text { know }\end{array}$ & \\
\hline More technical support & 70.4 & 29.6 & - & \\
\hline Public advertising & 72.7 & 36.7 & 0.6 & \\
\hline Possibility to delegate & 80.3 & 17.8 & 1.9 & \\
\hline Better training & 59.6 & 40.4 & - & \\
\hline Specific reimbursement & 59.0 & 39.1 & 1.9 & \\
\hline More time ${ }^{1}$ & 87.1 & 11.6 & 1.3 & \\
\hline Better recognized role & 73.3 & 25.5 & 1.2 & \\
\hline
\end{tabular}

(19.8\%) and newspapers (7.4\%) [32]. These data, collected more than 10 years ago, are still in line with ours. It seems that patients remain cautious and aware of the risks of referring to sources other than professionals, which is a satisfying result for family practice [25-27,31-33].
Table 3. Continued from the previous

\begin{tabular}{|c|c|c|c|c|}
\hline Variables & & eventive ca & & \\
\hline Do you propose ${ }^{2} .$. & $\begin{array}{l}\text { System- } \\
\text { atically or } \\
\text { often }\end{array}$ & $\begin{array}{c}\text { Some- } \\
\text { times or } \\
\text { never }\end{array}$ & $\begin{array}{l}\text { Don't } \\
\text { know }\end{array}$ & \\
\hline $\begin{array}{l}\text { HIV screening (at least } \\
\text { once for each patient) }\end{array}$ & 23.8 & 71.9 & 4.3 & \\
\hline Skin cancer screening & 54.6 & 45.4 & - & \\
\hline $\begin{array}{l}\text { Breast cancer screening } \\
\text { (according to } \\
\text { recommendations) }\end{array}$ & 55.9 & 43.6 & 0.6 & \\
\hline $\begin{array}{l}\text { Uterine cancer screening } \\
\text { (according to } \\
\text { recommendations) }\end{array}$ & 57.0 & 39.3 & 3.7 & \\
\hline $\begin{array}{l}\text { Colon cancer screening } \\
\text { (according to } \\
\text { recommendations) }\end{array}$ & 89.5 & 9.9 & 0.6 & \\
\hline $\begin{array}{l}\text { Prostate cancer screening } \\
\text { (for each patient above a } \\
\text { given age) }\end{array}$ & 58.8 & 41.2 & - & \\
\hline Do you propose ${ }^{2,3} \ldots$ & $\begin{array}{l}\text { Periodi- } \\
\text { cally }\end{array}$ & $\begin{array}{l}\text { Depending } \\
\text { on the } \\
\text { context }\end{array}$ & $\begin{array}{l}\text { On } \\
\text { patient } \\
\text { request }\end{array}$ & Never \\
\hline Blood sugar control & 51.6 & 62.7 & 36.6 & 0 \\
\hline Cholesterol control & 60.1 & 52.9 & 36.6 & 0 \\
\hline Blood pressure & 84.3 & 27.4 & 22.9 & 0.6 \\
\hline Weight & 96.1 & 22.2 & 22.9 & 0 \\
\hline $\begin{array}{l}\text { Do you practice } \\
\text { screening for }{ }^{3} . .\end{array}$ & $\begin{array}{l}\text { Periodi- } \\
\text { cally }\end{array}$ & $\begin{array}{l}\text { Depending } \\
\text { on the } \\
\text { context }\end{array}$ & $\begin{array}{l}\text { On } \\
\text { patient } \\
\text { request }\end{array}$ & Never \\
\hline Occupational risks & 9.6 & 80.8 & 37.7 & 5.4 \\
\hline Sleep disorders & 18.6 & 73.0 & 41.9 & 2.4 \\
\hline Depressive symptoms & 18.6 & 82.2 & 31.7 & 1.2 \\
\hline Cognitive problems & 22.4 & 82.0 & 38.3 & 0.6 \\
\hline Domestic violence & 2.4 & 87.4 & 56.9 & 11.4 \\
\hline $\begin{array}{l}\text { Do you propose seasonal } \\
\text { flu immunization to } \\
\text { high-risk patients }\end{array}$ & $\begin{array}{l}\text { System- } \\
\text { atically }\end{array}$ & Often & $\begin{array}{l}\text { Some- } \\
\text { times }\end{array}$ & Never \\
\hline & 86.4 & 11.7 & - & 1.8 \\
\hline
\end{tabular}

Values are presented as \%.

HIV, human immunodeficiency virus.

'German-speaking general practitioners excluded.

${ }^{2}$ By yourself or by another specialist (and you check the result).

${ }^{3}$ Not exclusives.

While GPs had positive overall attitudes to prevention, our findings were not homogeneous. In this respect, GPs' attitudes were positive regarding "classic" aspects of preventive care, such as cardiovascular risk factors and major addictions. The findings were, however, less clear-cut concerning other interventions, in particular occupational risk factors, affective and sexual life and, to a lesser extent, cannabis consumption. 

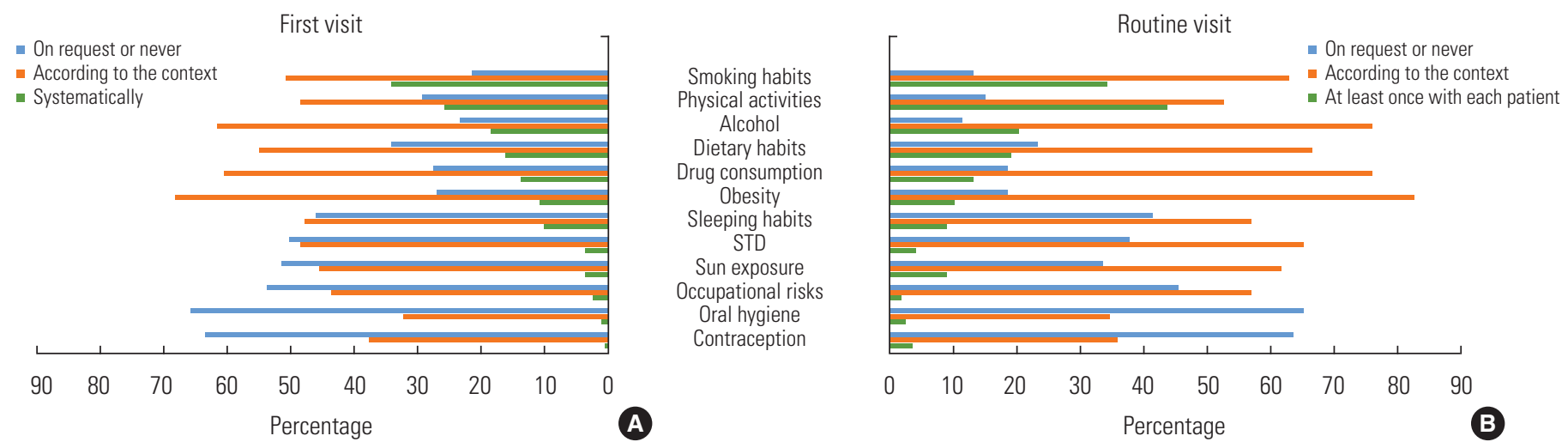

Figure 1. Primary prevention: practices of counseling in family medicine regarding various topics of prevention, (A) at the first consultation and (B) routine visits ( $n=167)$. STD, sexually transmitted disease.

These differences in GPs' attitudes were also observed in counseling. GPs routinely discussed topics, such as smoking and drinking habits, diet, and PA with patients on a first visit. In contrast, GPs and patients did not tend to discuss contraception, oral hygiene and, to a lesser extent, occupational risks and sun exposure. Patients also reported gaps in their knowledge for some topics. There was a large gap between their reported high degree of knowledge about major addictions (smoking and drinking habits, for which more than $90 \%$ of respondents stated that they were very well informed or informed) and their knowledge of other topics, in particular cannabis consumption (only $65 \%$ reported being very well or well informed) and new epidemics or vaccination. As a possible explanation, GPs may emphasize the difficulties of discussing some topics, especially cannabis consumption and affective and sexual life. Altogether, these findings indicate a need to broaden (or to modify) strategies in the field of preventive care. A first step could be improving GPs' training in the domain of primary preventive care. However, this is probably not sufficient, and practical tools might be more useful to guide physicians to be comfortable in domains other than addiction and cardiovascular risk factors.

Another concern is the variation in GP commitment according to the level of preventive care. Indeed, for secondary prevention such as cancer screening, GPs seemed to implement prevention satisfactorily if present in guidelines or within a specific clinical context. However, GPs rarely performed less standardized screenings spontaneously, such as screening for HIV, occupational risks, or depressive symptoms. Regarding primary prevention, vaccination seems obvious to most GPs and they generally practice it. In contrast, GPs rarely spontane- ously advertise health promotion through counseling. Whatever the prevention topic, counseling occurs mainly within a clinical context, instead of as a systematic approach. Holmberg et al. [21] described similar findings in 2014 among German GPs. In that study, the GPs justified their non-meddling attitude as avoiding the detrimental effect of uninvited healthbehavior suggestions on the patient-physician relationship. This is an interesting argument that should be taken into account in the debate on how and who should intervene in health promotion $[9,11,34,35]$. Regarding counseling activities in our study, PA and smoking habits were the 2 preventive activities most highlighted by GPs for health promotion. Smoking prevention is a standard topic of prevention. Effort in this prevention area over many decades has led to a decrease in the frequency of smoking among adults. Promotion of PA is more recent, and the fact that it was among the major prevention interests of the GPs is a positive finding.

Some ways to improve preventive care have already been pointed out in the literature, typically including more time, better training, and technical support. More innovative is the GPs' suggestion here to delegate preventive activities. Approximately 8 out of 10 physicians were in favor of this way of improvement. This is an interesting result, addressing a key issue in the future of family medicine, the transfer of some activities to other health professionals such as nurses or medical assistants. The presence of a "prevention practitioner" in family medicine practices has been tested and showed good results [2].

\section{Limitations and Strengths}

The representative nature of the GP and patient samples might be limited. Regarding GPs, despite random sampling 
and good representation in terms of age, sex, and rural/urban distribution [30], the low acceptance rate for participation in a practice-based network (although classically observed in this type of research) may introduce bias in the pool and therefore on other unmeasured characteristics. Moreover, the topic of the study could have led to the selection of GPs who were more favorable to prevention, generating overestimation in some results. Regarding patients, the participation rate was very good (above 70\%). However, the length of the questionnaire may have produced selection bias of population categories, in favor of retired or inactive people for example. This may have influenced the results.

Despite the unfavorable context of prevention within the healthcare system, preventive care in family medicine is reasonably good in Switzerland. This favorable situation may be partially explained by the "fee-for-time" payment offered to Swiss GPs, in addition to a fee-for-services remuneration.

Patients and GPs agreed about the crucial role of family medicine in delivering preventive care. However, 2 aspects of the delivery strategy need improvement: the first concern is the preference for highlighting mostly classical prevention areas (smoking, drinking, and dietary and PA habits), while rarely discussing others (occupational risks for instance) that deserves attention. The second relates to the strategy for preventive care, in particular the role of health promotion in primary care. Indeed, screening works relatively well, but needs improvement. In contrast, counselling activities are usually integrated into the clinical context and rarely as part of health promotion interventions. However, a comprehensive effort is probably needed to change the situation, extending the debate to include all the stakeholders to bring about a new way of thinking about preventive care and its role in society.

\section{CONFLICT OF INTEREST}

The authors have no conflicts of interest associated with the material presented in this paper.

\section{ACKNOWLEDGEMENTS}

The authors would like to thank the family physicians who are members of the SPAM family physicians network. They also want to thank the family physicians who agreed to test the questionnaire (Drs C. Arnold, J. Perdrix, M. Senn), and the fieldworkers who collected the data (R. Delacretaz, E. Dohner,
M. Einsiedler, E. Hansen, C. Marthe, J. Oplatka, E. Pratti, B. Rothlisberger, I. Wandelt).

The Bangarter Foundation and the Swiss Federal Office of Public Health supported the research summarized in this paper.

\section{AUTHOR CONTRIBUTIONS}

Conceptualization: NS, JC, CC. Data curation: FI, LB, PB. Formal analysis: CC. Funding acquisition: NS. Methodology: NS, CC. Writing - original draft: CC. Writing - review \& editing: CC, $\mathrm{FI}, \mathrm{LB}, \mathrm{PB}, \mathrm{JC}, \mathrm{NS}$.

\section{ORCID}

Christine Cohidon https://orcid.org/0000-0003-2343-500X Jacques Cornuz https://orcid.org/0000-0003-1276-9717 Nicolas Senn https://orcid.org/0000-0002-9986-3249

\section{REFERENCES}

1. Wagner $\mathrm{KH}$, Brath H. A global view on the development of non communicable diseases. Prev Med 2012;54 Suppl:S38-S41.

2. Grunfeld E, Manca D, Moineddin R, Thorpe KE, Hoch JS, Campbell-Scherer $\mathrm{D}$, et al. Improving chronic disease prevention and screening in primary care: results of the BETTER pragmatic cluster randomized controlled trial. BMC Fam Pract 2013;14: 175.

3. Tengs TO, Adams ME, Pliskin JS, Safran DG, Siegel JE, Weinstein $M C$, et al. Five-hundred life-saving interventions and their cost-effectiveness. Risk Anal 1995;15(3):369-390.

4. Klabunde CN, Lanier D, Breslau ES, Zapka JG, Fletcher RH, Ransohoff DF, et al. Improving colorectal cancer screening in primary care practice: innovative strategies and future directions. J Gen Intern Med 2007;22(8):1195-1205.

5. Robson J. Screening in general practice and primary care. $\mathrm{Br}$ Med Bull 1998;54(4):961-982.

6. Mitchell NS, Catenacci VA, Wyatt HR, Hill JO. Obesity: overview of an epidemic. Psychiatr Clin North Am 2011;34(4):717-732.

7. Wolf AM, Woodworth KA. Obesity prevention: recommended strategies and challenges. Am J Med 2009;122(4 Suppl 1):S19S23.

8. Brotons C, Björkelund C, Bulc M, Ciurana R, Godycki-Cwirko M, Jurgova $\mathrm{E}$, et al. Prevention and health promotion in clinical practice: the views of general practitioners in Europe. Prev 
Med 2005;40(5):595-601.

9. Calderón C, Balagué L, Cortada JM, Sánchez A. Health promotion in primary care: how should we intervene? A qualitative study involving both physicians and patients. BMC Health Serv Res 2011;11:62.

10. Crabtree BF, Miller WL, Tallia AF, Cohen DJ, DiCicco-Bloom B, Mcllvain $\mathrm{HE}$, et al. Delivery of clinical preventive services in family medicine offices. Ann Fam Med 2005;3(5):430-435.

11. Lawlor DA, Keen S, Neal RD. Can general practitioners influence the nation's health through a population approach to provision of lifestyle advice? Br J Gen Pract 2000;50(455):455459.

12. McAvoy BR. A scandal of inaction: how to help GPs implement evidence-based health promotion. Br J Gen Pract 2000;50(452): 180-181.

13. McAvoy BR, Kaner EF, Lock CA, Heather N, Gilvarry E. Our Healthier Nation: are general practitioners willing and able to deliver? A survey of attitudes to and involvement in health promotion and lifestyle counselling. Br J Gen Pract 1999;49(440): 187-190.

14. McKinlay E, Plumridge L, McBain L, McLeod D, Pullon S, Brown S. "What sort of health promotion are you talking about?": a discourse analysis of the talk of general practitioners. Soc Sci Med 2005;60(5):1099-1106.

15. Olesen F, Dickinson J, Hjortdahl P. General practice--time for a new definition. BMJ 2000;320(7231):354-357.

16. Yarnall KS, Østbye T, Krause KM, Pollak KI, Gradison M, Michener JL. Family physicians as team leaders: "time" to share the care. Prev Chronic Dis 2009;6(2):A59.

17. Badertscher N, Rossi PO, Rieder A, Herter-Clavel C, Rosemann $\mathrm{T}$, Zoller M. Attitudes, barriers and facilitators for health promotion in the elderly in primary care. A qualitative focus group study. Swiss Med Wkly 2012;142:w13606.

18. Bucher S, Maury A, Rosso J, de Chanaud N, Bloy G, PendolaLuchel I, et al. Time and feasibility of prevention in primary care. Fam Pract 2017;34(1):49-56.

19. Cornuz J, Ghali WA, Di Carlantonio D, Pecoud A, Paccaud F. Physicians' attitudes towards prevention: importance of intervention-specific barriers and physicians' health habits. Fam Pract 2000;17(6):535-540.

20. Geense WW, van de Glind IM, Visscher TL, van Achterberg T. Barriers, facilitators and attitudes influencing health promotion activities in general practice: an explorative pilot study. BMC Fam Pract 2013;14:20.

21. Holmberg C, Sarganas G, Mittring N, Braun V, Dini L, Heintze C, et al. Primary prevention in general practice - views of German general practitioners: a mixed-methods study. BMC Fam Pract 2014;15:103.

22. Luquis RR, Paz HL. Attitudes about and practices of health promotion and prevention among primary care providers. Health Promot Pract 2015;16(5):745-755.

23. Rubio-Valera $M$, Pons-Vigués $M$, Martínez-Andrés $M$, MorenoPeral P, Berenguera A, Fernández A. Barriers and facilitators for the implementation of primary prevention and health promotion activities in primary care: a synthesis through metaethnography. PLoS One 2014;9(2):e89554.

24. Eisner D, Zoller M, Rosemann T, Huber CA, Badertscher N, Tandjung R. Screening and prevention in Swiss primary care: a systematic review. Int J Gen Med 2011;4:853-870.

25. Anderson AS, Klemm P. The Internet: friend or foe when providing patient education? Clin J Oncol Nurs 2008;12(1):55-63.

26. Cline RJ, Haynes KM. Consumer health information seeking on the Internet: the state of the art. Health Educ Res 2001; 16(6):671-692.

27. Renahy E, Chauvin P. Internet uses for health information seeking: a literature review. Rev Epidemiol Sante Publique 2006;54(3):263-275.

28. Collet TH, Salamin S, Zimmerli L, Kerr EA, Clair C, Picard-Kossovsky $M$, et al. The quality of primary care in a country with universal health care coverage. J Gen Intern Med 2011;26(7): 724-730.

29. Patel A, Schofield GM, Kolt GS, Keogh JW. General practitioners' views and experiences of counselling for physical activity through the New Zealand Green Prescription program. BMC Fam Pract 2011;12:119.

30. Selby K, Cornuz J, Senn N. Establishment of a representative practice-based research network (PBRN) for the monitoring of primary care in Switzerland. J Am Board Fam Med 2015; 28(5):673-675.

31. Koch-Weser S, Bradshaw YS, Gualtieri L, Gallagher SS. The Internet as a health information source: findings from the 2007 Health Information National Trends Survey and implications for health communication. J Health Commun 2010;15 Suppl 3: 279-293.

32. McMullan M. Patients using the Internet to obtain health information: how this affects the patient-health professional relationship. Patient Educ Couns 2006;63(1-2):24-28.

33. Jacobs $W$, Amuta $A O$, Jeon $K C$. Health information seeking in the digital age: an analysis of health information seeking behavior among US adults. Cogent Soc Sci 2017;3(1):1302785. 
34. Grandes G, Sanchez A, Cortada JM, Balague L, Calderon C, Arrazola $A$, et al. Is integration of healthy lifestyle promotion into primary care feasible? Discussion and consensus sessions between clinicians and researchers. BMC Health Serv Res 2008; $8: 213$.
35. Johansson H, Stenlund H, Lundström L, Weinehall L. Reorientation to more health promotion in health services - a study of barriers and possibilities from the perspective of health professionals. J Multidiscip Healthc 2010;3:213-224. 